\title{
Synthesis and Characterization of Fe-doped Hydroxyapatite
}

\author{
S. F. Kabir ${ }^{a}$, S. Ahmed ${ }^{* b}$, A. I. Mustafa ${ }^{* a}$, M. Ahsan ${ }^{\text {b }}$, and S. Islam ${ }^{\mathrm{c}}$ \\ ${ }^{a}$ Department of Applied Chemistry and Chemical Engineering, University of Dhaka, Dhaka-1000, Bangladesh, \\ ${ }^{b}$ Institute of Glass and Ceramic Research and Testing (IGCRT), Bangladesh Council of Scientific and Industrial \\ Research (BCSIR) and ${ }^{c}$ Industrial Physics Division, BCSIR, Dhaka-1205, Bangladesh,
}

\begin{abstract}
Fe-doped hydroxyapatite bio-ceramic material has been successfully synthesized by wet chemical precipitation method using waste egg shell as Ca precursor and $\left(\mathrm{NH}_{4}\right)_{2} \mathrm{HPO}_{4}$ as $\mathrm{P}$ precursor. Two different concentrations of doping solutions $(0.1 \mathrm{M}$ and $0.05 \mathrm{M})$ were chosen and the developed apatite was characterized by using FT-IR, XRF, XRD and SEM techniques. Observed data were in excellent agreement with the standard values for hydroxyapatite which indicated successful formation of the Fe- doped apatite of different concentrations.
\end{abstract}

Key words : Fe-doped apatite, Hydroxyapatite, Biocompatible

\section{Introduction}

Hydroxyapatite (HA) being an analog material to bone and tooth mineral has been catagorized as biocompatible, bioactive and osteoconductive (bone bonding ability with surrounding tissues) (Webster T. J. et al. 2004, Ren F. et al. 2009, Miyaji F. et al. 2004). However, wider applications of synthetic HA are somewhat restricted due to its in-vivo solubility and inferior mechanical properties which limits its use in load-bearing application (Webster T. J. et al. 2004). Thus, to get rid of these problems, attempts have been initiated by the researchers to synthesize doped HA. Since flexible structure of HA permits suitable cationic and anionic substitutions to enhance the mechanical and physiochemical stabilities, doping treatment of HA has now become an important area of research (Mallick K. K. 2008, Gross K.A., et al. 2002, Tang Y. et al. 2009, Tas A. C. et al. 2007). Hence, now-adays researchers have put their best effort to develop modified synthetic apatites by the substitution or doping of chemical species found in natural bone. Such modification plays a significant role not only to produce HA with better mechanical and physiological stabilities but also to improve the suitability of HA for restoration of hard tissue such as bone and teeth (Tang Y. et al. 2009, Ren F. et al. 2009). Moreover, incorporation of such species is also considered to have enormous effects on the mineralization, demineralization and re-mineralization processes occurring in the calcified tissues (Kannan S. et al. 2008). For instance, fluoride-substituted hydroxyapatite has better thermal and chemical stabilities than hydroxyapatite (Eslami H. et al. 2008). However, vertebrate bone and tooth minerals are considered to contain HA structure with various substitution of $\mathrm{Na}^{+}, \mathrm{K}^{+}$, $\mathrm{Fe}^{3+}, \mathrm{Mg}^{2+}, \mathrm{Sr}^{2+}, \mathrm{Cl}^{-}, \mathrm{F}^{-}$ions (Wang J. et al. 2008, Donadel K. et al. 2009).

Iron is one of the trace elements in bone and teeth (Wang $\mathrm{J}$. et al. 2008) and it is a vital element in the circulatory system, essential for the functioning of numerous proteins in cells (Donadel K. et al. 2009). The presence of iron in HA lattice greatly influences its solubility and crystallinity (Wang J. et al. 2008). Bio-compatible ferromagnetic ceramic materials exhibit promising characteristic for some bio-medical and therapeutic applications such as hyperthermia treatment for cancer and tumor masses, magnetic resonance imaging and release of drug. Hyperthermia treatment usually involves an external energy source, but the drawback of using such an external energy source is that it is also absorbed by the normal tissue while passing through the body. So, to overcome this limitation application of ferromagnetic bio-ceramics has now received significant attention. Such bio-ceramics upon implementation, around the tumor acts as thermo seeds and heat the tumor locally to $42^{\circ}-46^{\circ} \mathrm{C}$ by their hysteresis loss when placed under an alternating field (Wu H.C. et al. 2007). It is to be noted that, normal cells are not affected at this temperature. Thus, hydroxyapatite doped with iron oxide can be used for the treatment of bone cancer by hyperthermia and

\footnotetext{
*Corresponding author. E-mail: ai_mustafa@yahoo.com; shanta_samina@yahoo.com
} 
also can promote the bone formation (Deb S et al. 2003). However, iron doped HA is super paramagnatic and also provides better biocompatibility than pure HA (Filho et al. 2008).

Considering the diverse role of iron in biological functions, we have attempted to synthesize iron doped apatite by using waste egg shell as the prime raw material of $\mathrm{Ca}$ source. This would, undoubtedly be cost-effective and beneficial for creating an effective waste management technology. Moreover, such an effort will be a blessing mostly for those countries in which bio-ceramics have presently been imported.

\section{Materials and Methods}

\section{Materials}

Chemicals used $\mathrm{FeCl}_{3}, \mathrm{NH}_{4} \mathrm{OH}, \mathrm{HNO}_{3},\left(\mathrm{NH}_{4}\right)_{2} \mathrm{HPO}_{4}$ were 99.99\% pure analar grade and obtained either from E. Merck or BDH. All the solutions were prepared using double distilled water.

\section{Synthesis of Fe-doped HA}

Prior to the synthesis of Fe-doped apatite, the egg shells were cleaned, powdered and characterized as described earlier (Kabir S. F. et al. 2011). Fe- doped HA was synthesized by wet chemical precipitation method (Kabir S. F. et al. 2011). However, requisite amount of egg shell powder was dissolved in conc. $\mathrm{HNO}_{3}$ and the $\mathrm{pH}$ of the solution was changed to 10.0 with aqueous ammonia. At this stage first doping solution $\left(0.1 \mathrm{M}\right.$ and $\left.0.05 \mathrm{M} \mathrm{FeCl}_{3}\right)$ was mixed with the egg shell solution followed by drop wise addition of ammoniacal $\left(\mathrm{NH}_{4}\right)_{2} \mathrm{HPO}_{4}(\mathrm{pH} 10.0)$ solution. A gelatinous precipitates of doped HA was formed which was kept for overnight and then filtered, washed and dried at $110^{\circ} \mathrm{C}$ to remove any trace of water. After oven drying calcinations was followed at $900^{\circ} \mathrm{C}$. The calcined sample was then crushed to fine powder which was then characterized. Pure $\mathrm{HA}(\mathrm{Ca} / \mathrm{P}=1.67)$ was also synthesized following the same procedure and analyzed for comparison.

\section{Characterization}

Fe-doped HA was first analyzed for the presence of $\mathrm{Ca}$ by Atomic absorption (AAS) spectroscopy and P by UV spectrophotometric method (Vogel 1962). The presence of functional groups were determined by Fourier transform infrared spectroscopy (FT-IR, Model No. FT-IR - 8900, SHIMADZU). Experimental spectra were obtained by using $\mathrm{KBr}$ disks with a 1:100 "samples-to-KBr" ratio and the samples were scanned in the wave number range of $4000 \mathrm{~cm}^{-1}$ $400 \mathrm{~cm}^{-1}$ with an average of 30 scans. The resolution of the

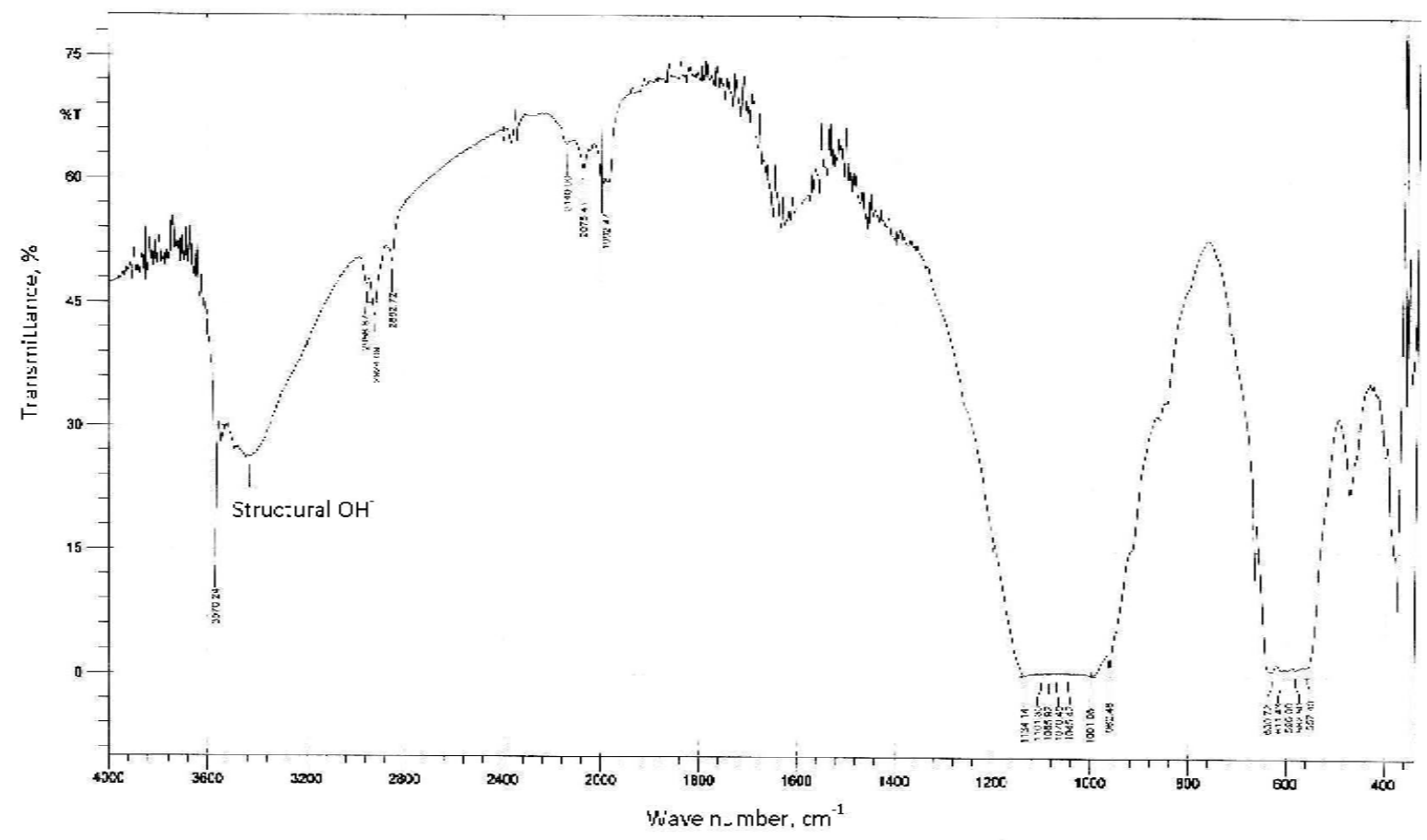

Fig. 1: FT-IR spectrum oven dried of $\mathrm{Fe}_{(0.1)} \mathrm{HA}$ 
spectrometer was $4 \mathrm{~cm}^{-1}$. Phase purity of the prepared samples was investigated by using PANalytical (X'Pert PRO XRD PW 3040). The intensity data were collected in 0.02 steps following the scanning range of $2 \theta=20^{\circ}-80$ using $\mathrm{CuK} \alpha(\lambda=1.54178 \mathrm{~A})$ radiation. The observed phases were compared and confirmed using standard JCPDS files as described in the following section.

\section{Results and Discussion}

Figure 1 shows the typical FT-IR spectrum of oven dried $\left(110^{\circ} \mathrm{C}\right)$ iron substituted apatite, synthesized by using $0.1 \mathrm{M}$ doping solution while Figure 2 presents the corresponding FT-IR of calcined $\left(900^{\circ} \mathrm{C}\right) \mathrm{Fe}$-doped apatite. The recorded XRD patterns of the Fe-doped synthesized apatite (at $110^{\circ} \mathrm{C}$ and $900^{\circ} \mathrm{C}$ ) are presented in Figures 3 and 4 respectively. SEM micrograph of the calcined $\left(\right.$ at $900^{\circ} \mathrm{C}$ ) doped apatites synthesized by using $0.1 \mathrm{M}$ and $0.05 \mathrm{M}$ doping solution are shown in Figures 5 and 6.

\section{FT-IR analysis}

The observed characteristic broad peaks (Figure 1) representing the phosphate $\left(\mathrm{PO}_{4}{ }^{3-}\right)$ group for the oven dried samples supported the formation of apatite. Additionally peaks for adsorbed water were also appeared in this case. However due to sintering at $900^{\circ} \mathrm{C}$ the broad peak of the $\mathrm{PO}_{4}{ }^{3-}$ group significantly changed to sharp and distinct peak (Figure 2). Particularly, the significant gap between the band positions of $\mathrm{PO}_{4}{ }^{3-}$ group at $563.1 \mathrm{~cm}^{-1}$ and $602.7 \mathrm{~cm}^{-1}$ suggested the formation of the hydroxy apatite (Ahmed et al. 2008). This result was then subsequently confirmed from the XRD data which has been summarized in the next section. The presence of small peak for C-O vibration bonds of carbonate group at $1423 \mathrm{~cm}^{-1}$ in Figure 2 provided the information that this sample contained carbonate ion and the presence of the carbonate ions promoted the incorporation of cation in the doped apatite (Kannan S. et al. 2008). The visualized band positions and their corresponding assignments for $0.1 \mathrm{M}$ and

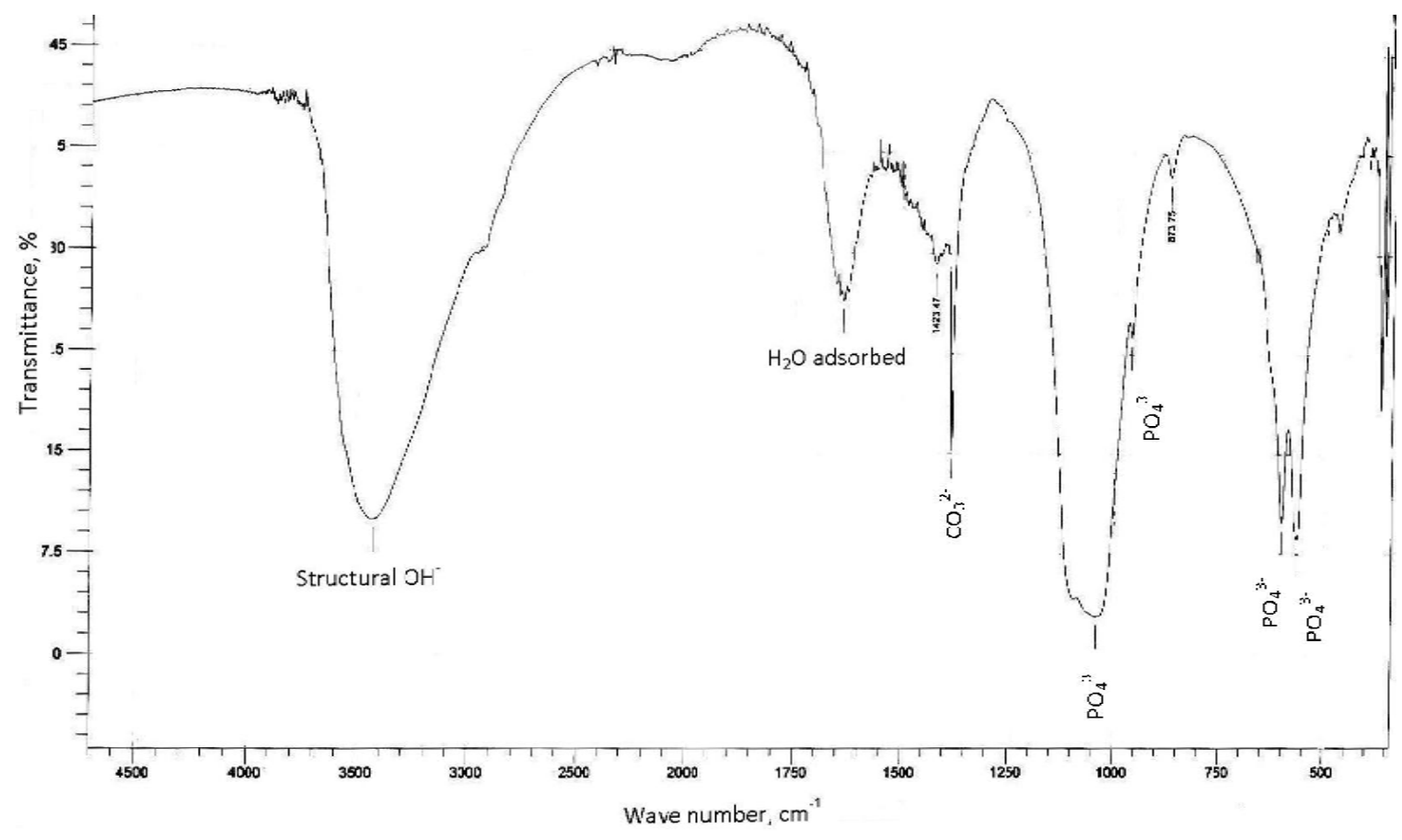

Fig. 2: FT-IR spectrum of calcined $\mathrm{Fe}_{(0.1)} \mathrm{HA}$

\section{Chemical analysis}

The presence of iron in the substituted hydroxyapatites was confirmed by XRF analysis which also provided the $\mathrm{Ca} / \mathrm{P}$ ratio of 1.66-1.67 compatible with the desired ratio of pure HA.
$0.05 \mathrm{M}$ Fe-doped apatites are tabulated in Table I. Clearly the characteristic band positions observed for both of the synthesized samples are in good agreement with that of pure HA (Kabir et al. 2011, Ahmed et al. 2008). This observation 
supported the formation of the expected cation substituted HA within the present experimental protocol.

Table I: FT-IR band positions and corresponding assignments of calcined pure and $\mathrm{Fe}$ doped apatites

\begin{tabular}{c|c|c|c}
\hline \multicolumn{2}{c|}{ Observed band positions $\left(\mathrm{cm}^{-1}\right)$} & \multirow{2}{*}{$\begin{array}{c}\text { Corresponding } \\
\text { assignments }\end{array}$} \\
\cline { 1 - 2 } Pure HA & $\mathrm{Fe}_{(0.05)} \mathrm{HA}$ & $\mathrm{Fe}_{(0.1)} \mathrm{HA}$ & \multicolumn{1}{|c|}{$\mathrm{PO}_{4}{ }^{3-}$ bending $\left(v_{4}\right)$} \\
570.9 & 561.2 & 565.1 & $\mathrm{PO}_{4}{ }^{3-}$ bending $\left(v_{4}\right)$ \\
601.7 & 602.3 & 603.7 & $\mathrm{PO}_{4}{ }^{3-}$ stretching $\left(v_{1}\right)$ \\
962.4 & 961.3 & 962.4 & $\mathrm{PO}_{4}{ }^{3-}$ bending $\left(v_{3}\right)$ \\
1039.6 & 1016.2 & 1014.56 & $\mathrm{CO}_{2}{ }^{3-}$ group $\left(v_{3}\right)$ \\
-------- & 1419.3 & 1423.47 & $\mathrm{H}_{2} \mathrm{O}$ adsorbed $\left(v_{2}\right)$ \\
1650.0 & 1633.2 & 1639.4 & Structural $\mathrm{OH}^{-}$ \\
3500.00 & 3231.52 & 3431.3 & \\
\hline
\end{tabular}

\section{XRD analysis}

The broad peaks of the XRD spectrum (Figure 3 ) of the oven dried $\left(\right.$ at $\left.110^{\circ} \mathrm{C}\right) \mathrm{Fe}$-doped apatite show the presence of amorphous phase which supports the observed FT-IR data.
The reason of this nature is the temperature effect. It is well established that the degree of crystallinity increases with the increase of sintering temperature resulting several distinct peaks. Thus this low crystallinity and amorphous nature have been significantly changed to well-defined crystalline HA phase after heating the sample at $900^{\circ} \mathrm{C}$ (Figure 4). Clearly a number of prominent peaks for apatite phase were in the XRD diffraction pattern. However, the observed intensity and d-spacing values for both the samples (synthesized by using $0.1 \mathrm{M}$ and $0.05 \mathrm{M}$ doping solution) are in excellent agreement with the JCPDS standard data for HA, (Ahmed et al. 2008) as shown in Table II. A good matching of the strong diffraction peaks at 20 positions $31.78^{\circ}(211)$ together with other two peaks at $32.26^{\circ}\left(\begin{array}{lll}1 & 1 & 2\end{array}\right)$ and $32.95^{\circ}\left(\begin{array}{lll}3 & 0 & 0\end{array}\right)$ ensured the formation of well crystallized doped apatite at $900^{\circ} \mathrm{C}$. This observation confirmed the formation of $\mathrm{Fe}$ substituted apatite of hexagonal structure and conclusively proved that a variety of substitutions of both cationic and anionic is possible in hydroxyapatite structure without any significant modification of its hexagonal system as mentioned in the previous investigation (Kannan et al. 2008).

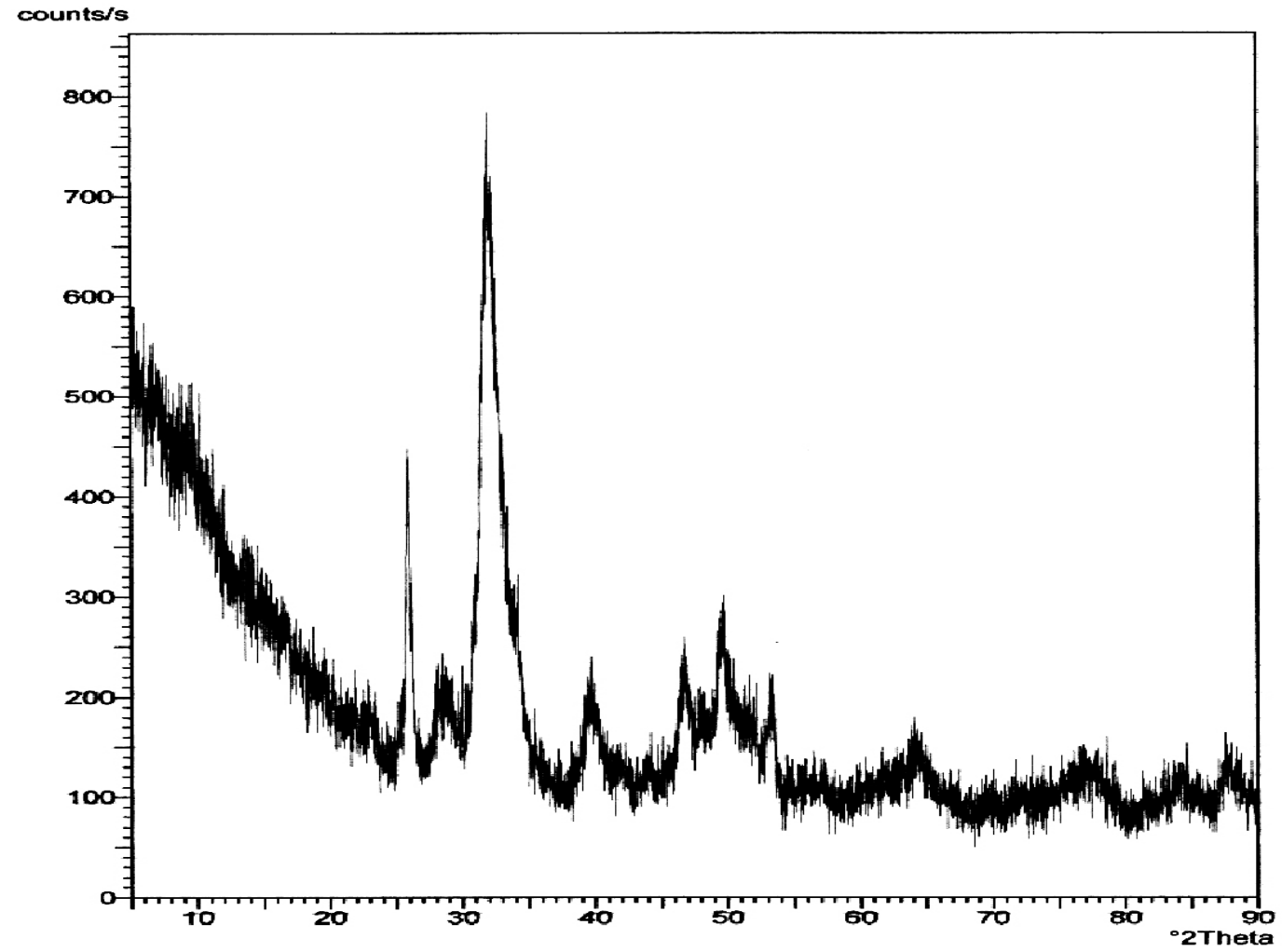

Fig. 3: XRD spectrum of oven dried $\mathrm{Fe}_{(0.1)} \mathrm{HA}$ 


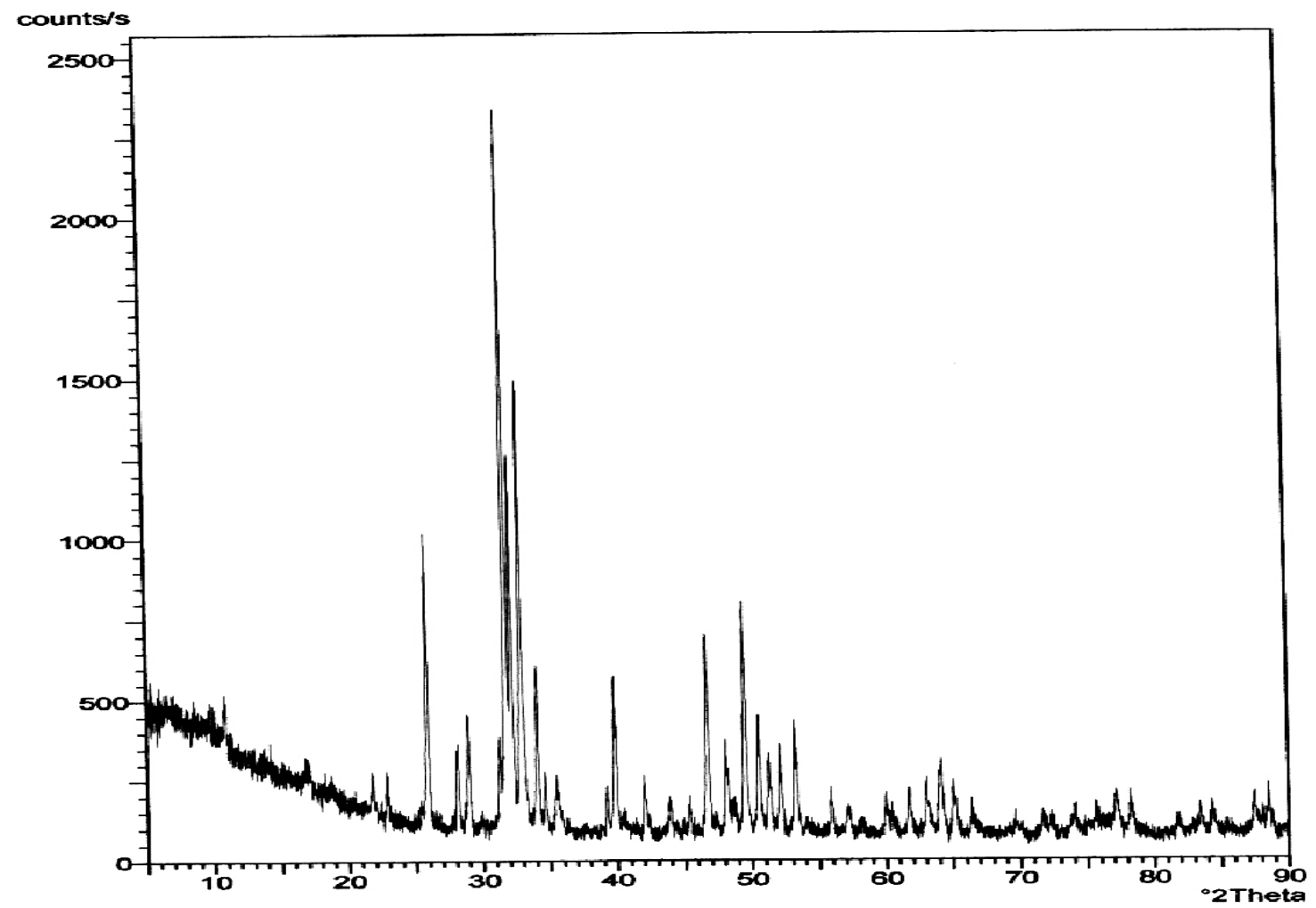

Fig. 4: XRD spectrum of calcined $\mathrm{Fe}_{(0.1)} \mathrm{HA}$

Table II: Relative intensity and $d$ - spacing (hexagonal unit cell) for calcined pure HA and Fe doped HA

\begin{tabular}{c|c|c|c|c|c}
\hline \multicolumn{2}{c|}{$\mathrm{Fe}(0.1) \mathrm{HA}$} & \multicolumn{2}{c|}{$\mathrm{Fe}(0.05) \mathrm{HA}$} & \multicolumn{2}{c}{ Pure HA } \\
\hline$d$ - spacing & relative intensity & $d$ - spacing & relative intensity & $d$ - spacing & relative intensity \\
\hline 4.0710 & 8.62 & 4.0787 & 9.28 & 4.0748 & 6.38 \\
3.8682 & 6.93 & 3.864 & 9.36 & 3.8999 & 4.45 \\
3.4332 & 52.03 & 3.4353 & 38.68 & 3.4395 & 38.68 \\
3.1835 & 12.35 & 3.1649 & 12.33 & 3.1673 & 8.36 \\
3.0824 & 12.31 & 3.0827 & 7.25 & 3.0861 & 14.60 \\
2.8068 & 100 & 2.8119 & 100.00 & 2.8152 & 100.00 \\
2.7735 & 61.11 & 2.774 & 52.90 & 2.7744 & 59.40 \\
2.7180 & 59.53 & 2.7148 & 62.30 & 2.7183 & 55.42 \\
2.6279 & 13.03 & 2.6298 & 20.99 & 2.6296 & 23.44 \\
2.5238 & 27.23 & 2.5257 & 6.93 & 2.5271 & 5.30 \\
2.2589 & 7.88 & 2.2604 & 22.47 & 2.2619 & 19.31 \\
2.1450 & 24.11 & 2.1480 & 8.60. & 2.1482 & 5.28 \\
2.0587 & 6.71 & 2.0594 & 5.27 & 2.0610 & 5.54 \\
1.9417 & 5.10 & 1.9427 & 26.62 & 1.9443 & 28.19 \\
1.8879 & 28.63 & 1.8891 & 13.43 & 1.8914 & 14.58 \\
1.8414 & 15.17 & 1.8344 & 17.07 & 1.8413 & 32.19 \\
1.8044 & 27.79 & 1.8042 & 15.39 & 1.8060 & 15.67 \\
1.7789 & 17.08 & 1.7778 & 11.76 & 1.7806 & 11.83 \\
1.7534 & 12.84 & 1.7538 & 12.50 & 1.7538 & 12.30 \\
\hline
\end{tabular}


The crystallite size, crystallinity and cell volume of both of the calcined (at $900^{\circ} \mathrm{C}$ ) doped samples were calculated as described previously (Kabir S. F. et al. 2011). The calculated values are tabulated in Table III. The lattice parameters and cell volume values of the $0.05 \mathrm{M} \mathrm{Fe}$-doped apatite did not significantly change as compared to those of pure HA (Kabir S. F. et al. 2011) but in case of $0.1 \mathrm{M}$ doped apatite, lattice parameters and cell volume values are lower than that observed in case of pure HA (Kabir S. F. et al. 2011). However for both cases lower values of crystallite size and crystallinity were observed as substitution significantly reduces the crystallite size as well as crystallinity (Mallick K. K. 2008). Possibly, the changes in cell volume for the later case would be due to the substitution of more cation (since $0.1 \mathrm{M} \mathrm{Fe}$ doping solution was used in this case).

Table III: Crystallographic information of calcined Fe apatites

\begin{tabular}{c|c|c|c}
\hline Parameters & $\begin{array}{c}\text { Calcined } \\
\mathrm{Fe}(0.05 \mathrm{M}) \mathrm{HA}\end{array}$ & $\begin{array}{c}\text { Calcined } \\
\mathrm{Fe}(0.1 \mathrm{M}) \mathrm{HA}\end{array}$ & Calcined HA \\
\hline Lattice parameter $a=b$ & 9.42 & 9.40 & 9.42 \\
$c$ & 6.87 & 6.85 & 6.88 \\
Crystallinity, $\mathrm{X}_{\mathrm{c}}$ & 4.37 & 3.54 & 5.03 \\
Crystal size $\left({ }^{\circ} \mathrm{A}\right)$ & 525.39 & 467.09 & 752.37 \\
Volume & 1578.30 & 1567.70 & 1580.60 \\
\hline
\end{tabular}

\section{SEM analysis}

Since the synthesized Fe-doped apatite showed the presence of crystalline phase after sintering at $900^{\circ} \mathrm{C}$ so the morphology and micro structural nature of the Fe substituted apatites synthesized at this temperature were observed by SEM (Figures 5 and 6). No significant shapes such as hexagonal, spherical, etc. are observed.

\section{Conclusion}

Fe substituted or doped hydroxyapatite has been successfully synthesized from egg shell for the first time, which could be a potential and cost-effective bio-ceramic material for bone substitution in surgery, orthopedics and dentistry fields. The synthesized doped apatites were characterized by XRF, FT-IR, XRD and SEM techniques and resembled the characteristics of pure HA. Further investigation will be carried out considering the effects of the sintering temperature and doped solution concentration. However, incorporation of such cation in hydroxyapatite structure will play a vital role to enhance the bioactivity and physiochemical properties of the apatite. On the other hand utilization of egg shell will open up an effective trail for waste management through material re-cycling approach which will ultimately be a significant step towards a green and clean environment.

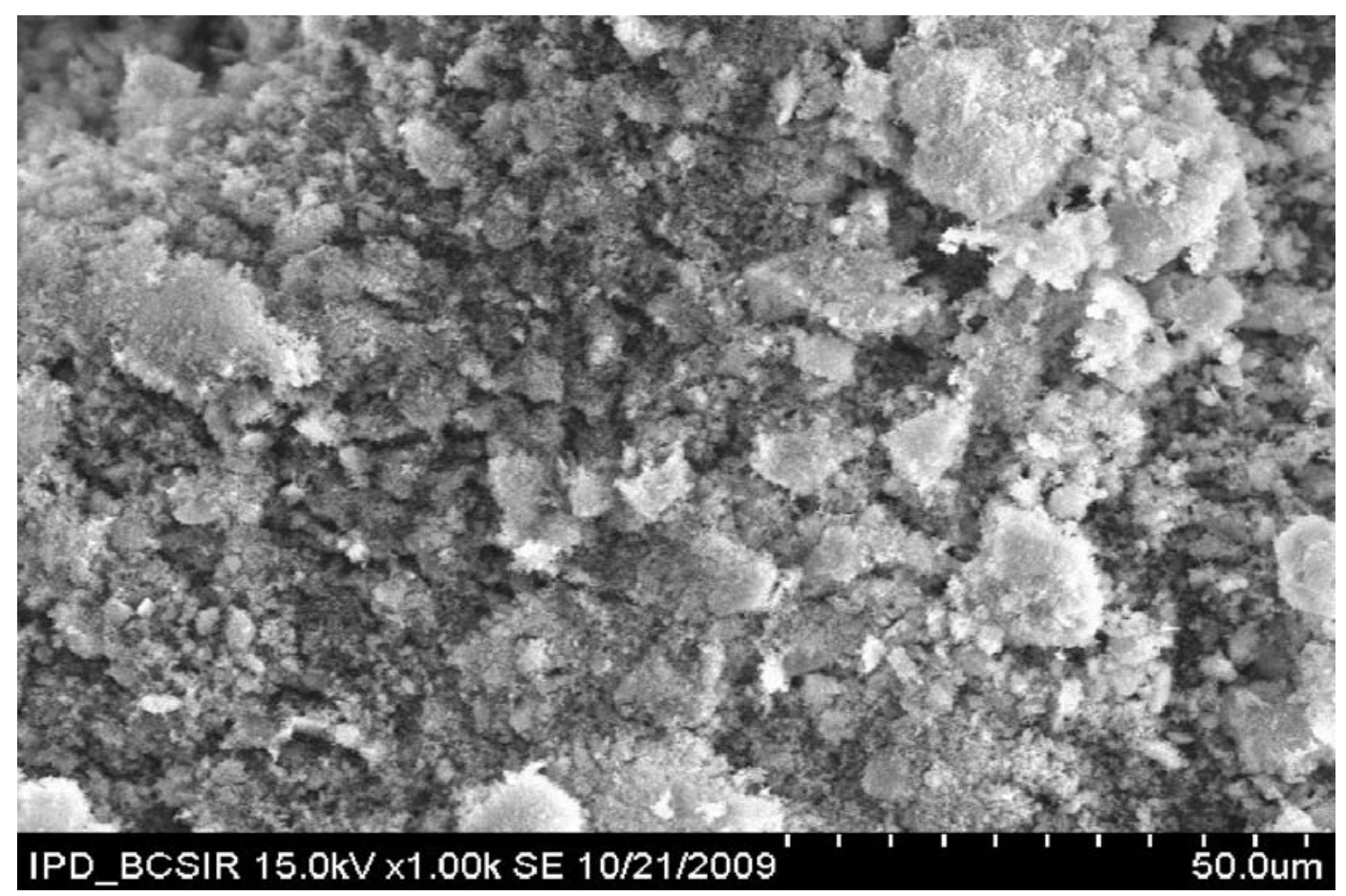

Fig. 5: SEM micrograph of calcined $\mathrm{Fe}_{(0.1)} \mathrm{HA}$ 


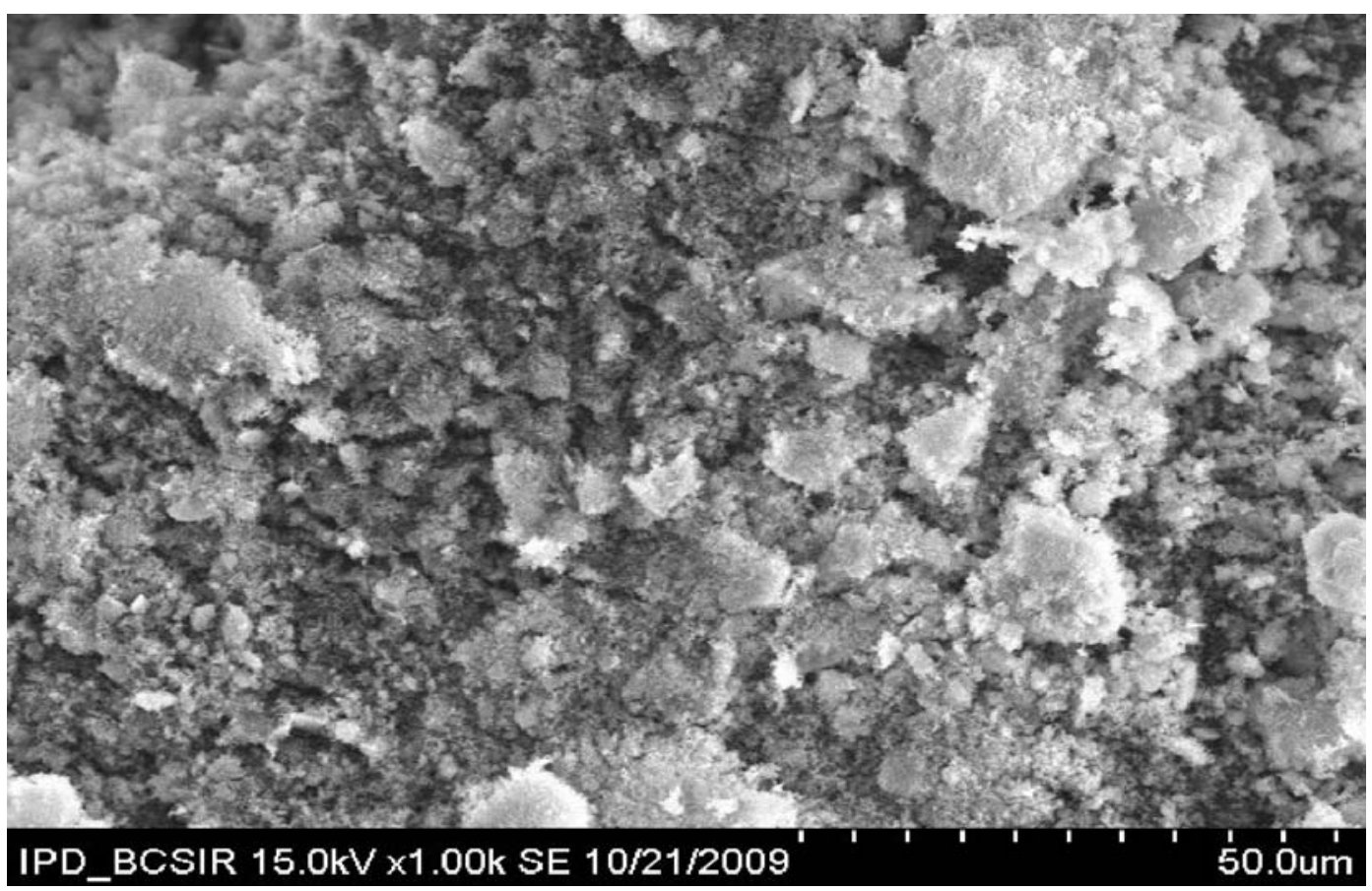

Fig. 6: SEM micrograph of calcined $\mathrm{Fe}_{(0.05)} \mathrm{HA}$

\section{Acknowledgement}

We acknowledge the financial support from IGCRT, BCSIR and the assistance of Dr. Mohammad Mizanur Rahman, Associate Professor of ACCE, DU for FT-IR. We also appreciate the generosity of the Ministry of Science and Technology, Government of Bangladesh for granting the NSICT fellowship to SFK and special allocation project to SA.

\section{References}

Ahmed S. and Ahsan M. (2008). Synthesis of Ca-hydroxyapatite bioceramic from egg shell and its characterization, Bangladesh J. Sci. Ind. Res. 43 (4): 501-512.

Deb S., Giri J., Dasgupta S., Datta D. and Bahadur D. (2003). Synthesis and characterization of biocompatible hydroxyapatite coated ferrite, Bull. Mater. Sci. 26 (7): 655-660.

Donadel K., F m. D.V. and Laranjeira M. C. M. (2009). Preparation and characterization of hydroxyapatitecoated iron oxide by spray-drying technique, Anais $d a$ Academia Brasileira de Ciências 81(2): 179-186.

Eslami H., Solati-Hasjin M. and Tahriri M. (2008). Synthesis and Characterization of Hydroxyapatite
Nanocrystals via Chemical Precipitation Technique, $J$. of Ceramic Processing and Research, 4(2): 127-134.

Filho F. P., Nogueira R. E. F. Q., Grac-a M. P. F., Valente M. A, Sombra A. S. B. and Silva C. C. (2008). Structural and mechanical study of the sintering effect in hydroxyapatite doped with iron oxide, Physica B 403(19-20): 3826-3829.

Gross K. A., Jackson R., Cashion J. D., and RodriguezLorenzo L. M. (2002). Iron substituted apatites: a resobable biomaterial with potential magnetic properties, European Cells and Materials. 3 (2): 114-117.

Kannan S., Ventura J. M. G., Lemos A. F., Barba A. and Ferreira J. M. F. (2008). Effect of sodium addition on the preparation of hydroxyapatites and biphasic ceramics, Ceramics International. 34: 7-13.

Kabir S. F., Ahmed S., Ahsan M. and Mustafa A. I. (2011). Zinc Substituted hydroxyapatite from waste Ca source, Dhaka University Journal of Applied Science and Engineering.1(2): 81-87.

Miyaji F., Kono Y. and Suyama Y. (2004). Formation and structure of zinc-substituted calcium hydroxyapatite, Materials Research Bulletin. 40: 209-220. 
Mallick K. K. (2008). Development, synthesis and characterisation of porous biomaterial scaffolds for bone tissue engineering, Ceramic Transactions Proceedings, American Ceramic Society, 9(3): 7-13.

Ren F., Xin R., Ge X.and Leng Y. (2009). Characterization and structural analysis of Zinc-substituted hydroxyapatites, Acta Biomaterial. 5: 3141-3149.

Tas A. C., Bhaduri S. B. and Jalota S. (2007). Preparation of $\mathrm{Zn}$-doped $\beta$-tricalcium phosphate $\left(\beta-\mathrm{Ca}_{3}\left(\mathrm{PO}_{4}\right)_{2}\right)$ bioceramics, Materials science and engineering. 27: 394401.

Tang Y., Chappell H. F., Dove Martin T., Reeder Richard J. and Lee Young J. (2009). Zinc incorporation into hydroxyapatite, Biomaterials. 30: 2864-2872.
Vogel A. I (1962). A Text Book of Quantitative Inorganic Analysis Including Elementary Instrumental Analysis, 3rd Edition, The English Language Book Society and Longman, pp 810.

Webster T. J., Massa-Schlueter E. A., Smith J. L. and Slamovich E. B., (2004). Osteoblast response to hydroxyapatite doped with divalent and trivalent cations, Biomaterials. 25: 2111-2121.

Wu H. C., Wang T. W., Sun J. S., Wang W. H. and Lin F. H. (2007). A novel biomagnetic nanoparticle based on hydroxyapatite, Nanotechnology 18165601 (9pp) doi:10.1088/0957-4484/18/16/165601.

Wang J., Nonami T. and Yubata K. (2008). Syntheses, structures and photophysical properties of iron containing hydroxyapatite prepared by a modified pseudo-body solution, J Mater Sci: Mater Med, 19: 2663-2667.

Received: April 17, 2011;

Accepted : September 11, 2011 